\title{
ルイス・カーンのキンベル美術館の設計分析 建築設計における形式とボキャブラリー \\ A MORPHOLOGICAL ANALYSIS ON THE DESIGN PROCESS OF LOUIS I. KAHN'S KIMBELL ART MUSEUM \\ Form and vocabulary in architectural design
}

\author{
富岡 義人* \\ Yoshito TOMIOKA
}

\begin{abstract}
This paper is to reconstruct the design process of Louis I. Kahn's Kimbell Art Museum through a morphological analysis of the basic form and its vocabulary which were applied by the Architect. The sequence of the discussion is as following :

1) An analysis of design sketches etc. to induce the basic form and its vocabulary.

2) An examination of their adaptability to the Museum's architectural program.

3) An explanation of the vault, the main vocabulary in the design, which plays an important role in controlling the relationship between program requirements and formal transformations in the design.
\end{abstract}

Keywords : Louis I. Kahn, Kimbell Art Museum, design process, design method, form, design vocabulary. ルイス・カーン, キンベル美術館, 設計過程, 設計方法, 形式, ボキャブラリー

1.はじめに

本稿は、ルイス・カーン (1901-1974)のキンベル美術 館 (1966-1972) の設計過程を分析して、この設計にお いて建築形態が果した役割を探ることを目的とするもの である。同時に、この分析は建築形態を対象とする分析 的な研究を建築作品の創作に積極的に関係づけようとす るひとつの試みでもある。

キンベル美術館は、個人コレクションが発展して設立 された美術館であり、アメリカ合采国テキサス州フォー トワースの文化施設が集中する公園地区に立地している 1)。この美術館は、20世紀後半の現代建築を代表する古 典的作品のひとつとして、建築家から一般の人にまで、 梁く愛されている作品である。

キンベル美術館の設計過程を知るための材料は、残さ れたスケッチやオフィス・ドローイング、模型などであ る。これらは、ペンシルベニア大学建築資料館 ルイス. カーン・コレクションに整理・保存され、このうちカ ーン自筆のドローイングは、一般にガーランド版と呼ば れる図集にまとめられているが。以本稿中ではGARの
記号で表す。これに揭載されたキンべル美術館に関する 196枚のスケッチのうちで、約半数にカーン自身や事務 所員の手によって日付が付されており、設計過程を再構 成するための貴重な手がかりを与えている。また、その 他のオフィス・ドローイングなどは、ロナーとジャべリ による作品集が詳しい文。以下本稿中ではR\&Jの記号で 表す。

また、この作品の設計過程について、建築史学的に詳 しく調查した先行研究として、パトリシア・カミングス . ルードによる3編の著作がある。これらをPCL1, ${ }^{5)}$ PCL $2,{ }^{6}$ PCL $3{ }^{7)}$ の記号で表す。特にPCL1，PCL2には多 くの図版が揭載されている。

以上のように、キンベル美術館については、その設計 過程の全体的な再構成に十分な資料や先行研究があり、 本稿の分析意図にふさわしい得難い事例のひとつである と言える。

なお、研究の性質上、関係する図版は多数に及ぶが、 そのすべてを揭げることはできないので、必要な場合に は適宜前揭書を参照していただきたい。 


\section{2. 設計分析}

\section{1 設計分析の方法}

建築設計には機能的条件、技術的条件などの様々な設 計条件が課され、設計者はそれらを満たすために、形態 を変換しながら設計を進め、最終的に作品形態を結実さ せる。この関係を一見すると、設計条件は建築設計を進 行させる原動力であり、形態は設計条件に従って造り出 されるように考えられるであろう。しかし逆に言えば、 設計条件の満足は、それに適合する変換形態を生成させ る形態自身の能力によって条件づけられていることとな る。これを形態内在的条件と呼ふ（以下、内在的条件と 略す） ${ }^{8)}$ 。建築設計とは、設計条件と内在的条件を呼応 させあいながら、形態を変換し続け、ついに両者が適合 しあった状態を決定する行為であり、設計過程はこの行 為の邈った道筋なのたと考えられる9。るして、このよ うに捉えるならば、建築形態は、多様な設計条件を代理 し、総合する、建築設計の思考の道具であると言えるで あろう。

以上の点を踏まえて、設計分析は3段階に分けて行う ことにする。すなわち、キンベルの設計過程のスケッチ 等からの形態の変換の読み取り（2.2で論ずる）、設計 過程を導いた内在的条件の分析（2.3で論ずる）、内在 的条件と設計条件との関係の分析 (2.4で論ずる) であ る。

\section{2 設計における形態変換}

まず残された設計スケッチの整理を通じて形態の変換 を捉える。カーン自筆のスケッチ拉よびオフィス・ドロ ーイング等について、日付の付されたものを月単位で時 間的に順列し、また、日付はないが、形態の特徽から時 期の同定されるものは、その旨の記号を付して挿入した。 この結果を表1に示す。縦軸に時間、横軸にはスケッチ の対象となっている構成要素を示している。

この表から、取り扱われる構成要素が一致し、図法、 描法の似かよった設計スケッチ等のまとまりを見いだす ことができる。このまとまりは、設計における思考の単 位を反映していると考えられるので、これをスタディと 呼び、表1の中で点線でくくって示している。ここでは、 スタディをヴォールトに関するものと平面計画に関する ものに大きくふたつに分けて説明する ${ }^{10) 。}$

・ヴォールトのスタデイ1 1967年3月ごろ

1967年3月ごろの、キンベルの最初のスタデイは、ヴ オールトの断面を図式的に描いたスケッチ群からなるも のである（図1）。ここでカーンは、建物の全体形を細 長いヴォールトの結合体であると構想し、単位となるヴ
オールトの形態の可能性を探索している。スケッチに示 されたヴォールトのバリエーションは、折板を用いるも のと、曲面を用いるものの2種に分けられ、かつそれぞ れに、ヴォールトひとつが単位となるものと、ふたつが 一組で単位となるものがあって、合計 4 種に分類するこ とができる（図2）。このことは、このスタデイが、特 定の細部を細かく検討するというよりも、様々な形態を 広く走査しようという意図を持ったものであることを示 している。

この段階のすべてのスケッチで、ヴォールト同士は直 接連結され、頂部に採光部がとられている。また、一部 のスケッチでは空調ダクトが採光部の下などに納められ ているが、この問題は全てのスケッチで統一的に解かれ ているものではない。また、スケッチの中には、直接光 の入射軌跡が描かれたものがあり、この段階では、採光 の問題が自然光の直接の導入として考えられていること を示唆している。これらのヴォールトのうちから単体の 折板ヴォールトが、後に述べる第一案の正方形案の形態 要素として採用されている。

図 1 ヴォールトの断面のスケッチ

Louis I. Kabn Collection, University of Pennsylvania and Pennsylvania Historical and Museum Commission 730.137

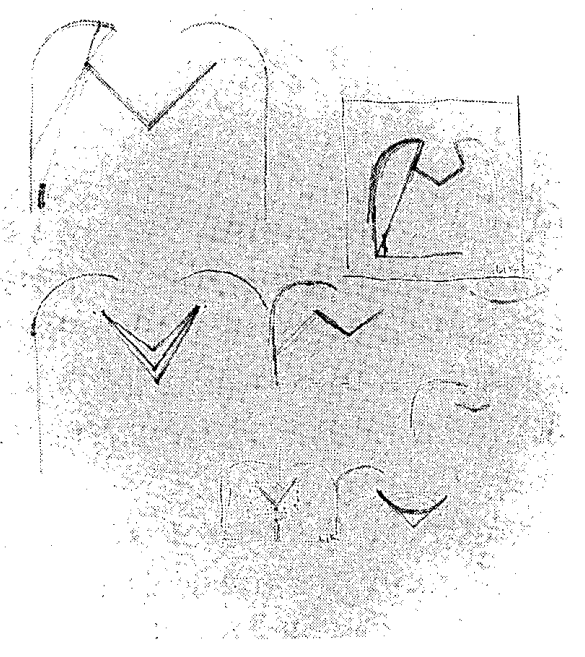

图 2 サォールトのスタディ1に扔けるバリエーション

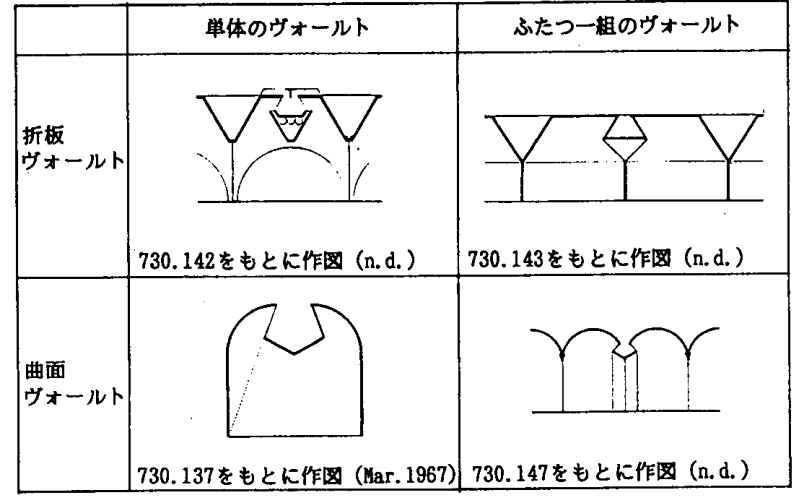


表 1 設計スケッチ等の時間的順列

\begin{tabular}{|c|c|c|c|c|c|c|}
\hline 年月 & 配置計画 & 配置詳細 & 座面計画 & クォールト & 特定の室計面 & 細部詳細 \\
\hline $1967 / 3$ & $\begin{array}{l}\text { I正方形案の敷地 } \cdot \text { 平面 } \\
\mathrm{I}, 2,3,4 \\
\mathrm{PCL} 2-10 \mathrm{M} \\
\mathrm{PCL} \\
\mathrm{L}\end{array}$ & のスタディ & 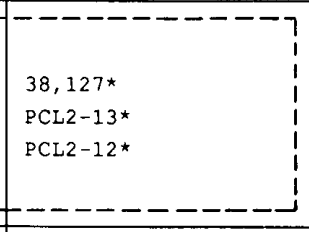 & 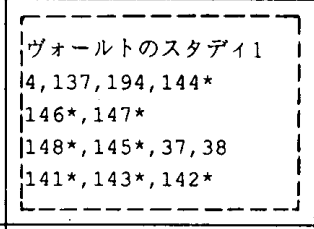 & & \\
\hline $1967 / 7$ & 形平面案の敷地・平 & 面のスタアィ & -----------7 & 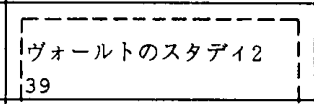 & & \\
\hline $1967 / 9$ & $\begin{array}{l}5,195 \mathrm{P}, 196 \mathrm{P} \\
\mathrm{R} \& \mathrm{~J}-10 \mathrm{P}, \mathrm{R} \& \mathrm{~J}-11 \mathrm{P}\end{array}$ & & $\begin{array}{l}5, \mathrm{PCL} 2-18^{\star} \\
122,123\end{array}$ & \begin{tabular}{|l|}
$138,81^{\star}, R \& J-22$ \\
$R \& J-23, R \& J-24, R \& J-25 !$
\end{tabular} & & \\
\hline $1967 / 11$ & $\left.\right|^{\mathrm{PCL} 2-26 \mathrm{M}}$ & & \begin{tabular}{l|l}
$83 \#, 40$ & $\mid$ \\
PCL2 $-24 *, P C L 2-25 *$ & $\mid$ \\
\end{tabular} & 1 & $m$ & \\
\hline $1967 / 12$ & $\perp$ & & & PCL2-23 & & \\
\hline $1968 / 1$ & 1 & & & 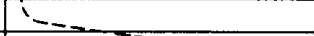 & & PCL2-28S \\
\hline $1968 / 5$ & + & & PCL1-48 & $-\cdots-\cdots$ & & \\
\hline $1968 / 6$ & 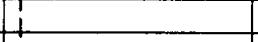 & 6 & 41,42, PCL2-33 & & $-\cdots$ & \\
\hline $1968 / 7$ & I & - - - - - - - & PCL2 244 & & 139,43 & 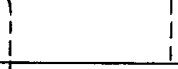 \\
\hline $1968 / 8$ & $\begin{array}{l}\text { 変莩期の敷地・平面の } \\
155^{*} \\
7,8,24 \text { * } \\
23 * \\
23 *\end{array}$ & 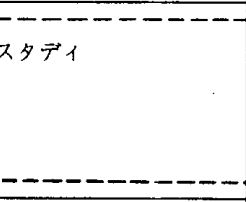 & $\begin{array}{l}-----\cdots-- \\
44,85^{\star}, 46 \\
82 \# \\
48,49,151 *\end{array}$ & & 45,47 & $\begin{array}{l}1 \\
1 \\
1 \\
1 \\
1 \\
1 \\
1 \\
1\end{array}$ \\
\hline $1968 / 9$ & $\begin{array}{l}\text { 外構計面のスタディ } \\
17 *\end{array}$ & $-------\rceil$ & $\begin{array}{l}\text { C 形平面案の平面スタデイ } \\
\text { |PCLL2-38,PCL2-39 }\end{array}$ & & 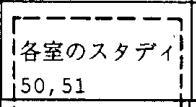 & i \\
\hline $1968 / 10$ & 110 & 9 & I 1 & & $52,53,54,55$ & 1 \\
\hline $1968 / 11$ & PCL2-46M & 156 & PCL2-44,PCL2-45 & & 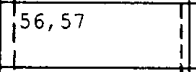 & $i$ \\
\hline $1969 / 1$ & & & 1 & & 1 & IPCL2-62L \\
\hline $1969 / 3$ & 1 & & $\begin{array}{l}\text { 61 } 61 \# \#, 58, \text { PCL2 }-47 \\
\text { PCL2 }-48, \text { PCL2 }-49\end{array}$ & & 1 & PCL2-63 \\
\hline $1969 / 5$ & $118 *, 11$ & & $52 \ldots \ldots \ldots$ & & 59,60 & \\
\hline $1969 / 6$ & IPCL2-54 & & & & & \\
\hline $1969 / 7$ & & & & . & 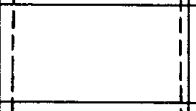 & $\begin{array}{l}15 \text { 湅部のスタデイ } \\
157\end{array}$ \\
\hline $1969 / 8$ & & $i$ & & & + & 124 \\
\hline $1969 / 9$ & & 158 & & & 162,63 & \\
\hline $1969 / 10$ & & $12,64,13,14,14.1]$ & & & 65 & \\
\hline $1969 / 11$ & & & & & 66 & 159 \\
\hline $1969 / 12$ & & 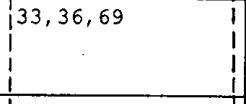 & & & $\begin{array}{l}170,125,67,68 \\
71,72,73 \\
74,126,75\end{array}$ & $\begin{array}{l}160,30,162 \\
163,164 \\
165\end{array}$ \\
\hline $1970 / 1$ & & $\begin{array}{l}167,168,169,170, \\
171,172,173\end{array}$ & & & 776,140 & $\begin{array}{r}166,174 \\
175,176 \\
\end{array}$ \\
\hline $1970 / 3$ & & & & & $77+78,72=-$ & \\
\hline $1970 / 5$ & & i & & & & 177 \\
\hline $1970 / 6$ & & + & & & & GER \\
\hline $1970 / 8$ & & 180 & & & & \\
\hline$\frac{1970 / 12}{1072 / 8}$ & & !1 78 & & & & \\
\hline $1972 / 8$ & & & & & & $179,179.2$ \\
\hline
\end{tabular}

凡例

図版番号

・無印 GAR 所収のスケッチの図版番号を示す。キンベル美術館 の作品番号の730.を省略した。

OPCL1 PCL1に所収のスケッチ、図面の図版番号を示す。

OPCL2 PCL2に所仪のスケッチ、図面、模型の図版番号を示す。 章番号を指す3.を省略した。

○R\&J R\&Jに所収のスケッチ、図面の図版番号を示す。キンベル 美術館の作品茹号のKAMを省略した。

OGER カーンと共同設計を行なったGeren社による実施設計図を 示す。Michael Brawne, Kimbell Art Museum, Louis I. Kahn, Phaidon Press Ltd., 1992. に所纡の図面参照。

添字

-・時期の特定されるスケッチとの形態的特徽の一致によって、 特期同定を行なったことを示す。

- \#PCL2の時期同定を採用したことを示す。

— \# GAR 700.61 のキャブションに誤植がある。時期は、16 March, 1969 が正しい。

P 透視図を示す。

M 模型を示す。

O S August E. Kommendant による構造図を示す。

- L Richard Kellyによる探光部反射板の図面を示す。 
・ヴォールトのスタディ 2 1967年7月から1969年3月 1967年7月のヴォールト断面のスケッチ（図3）は、 それ以降の全てのスタディの基本を確立した重要なもの である。ヴォールトの断面は半円形の輪郭を持ち、相互 に間隙を介して結合されている。この間隙は、のちに地 下階へのライト・ウェルや、空調ダクトを収容する空間 として活用されることとなる。ヴォールトのスタディ 1 で散発的にあらわれていた問題を統合的に処理するため に必要な道具立てが、このスケッチを契機に成立したと 考えられる。さらに採光部については、自然光が反射板 によって天井面に拡散されるように変更されている（図 $4, \mathrm{~A}, \mathrm{~B})$ 。

これ以降、担当の所員であったマイヤースは、ヴォー ルト頂部の空間容積を堿じた、様々な案を作成する（図

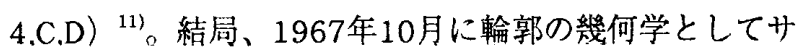
イクロイド曲線が採用され、ヴォールトの形態変換は、 構造、設備の検討を経て、次第に細部へと移っていく ${ }^{22}$ 13)

次に、配置・平面計画の形態変換について説明する。

・正方形案の配置・平面のスタディ 1967年3月ごろ このスタディはヴォールトのスタディ1と平行して行 われた。細長い折板ヴォールトが相互に連結されて、ほ ほ正方形の平面を形づくっている。建物の各所には中庭 が取られ、周囲はアーケードで取り囲まれている。建物 のほほ中央部を南北に横切るように取られた大きな中庭 には、キンベルの建設に当たって廃止された道路の並木 が残されている。この中庭によって、建物は東西二つの ウイングに分けられている。残念ながら、細かい内部空 間の処理や、その機能については、残された資料からは 十分に読み取ることができない。

配置計画については、前庭や池など、最終案にまで引 き継がれることになる形態要素がすでに用いられて、外

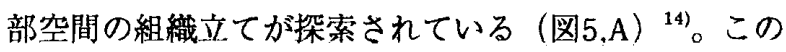
スタデイに基づいて第一案である正方形案の図面と模型 が作成された。

・H形平面案の配置・平面のスタアィ 1967年9月から 1968年7月

このスタデイは、1967年9月から1967年11月に行な われた前期のものと、1968年5月から1968年7月に行な われた後期のものに大別される。

前期のものは、ヴォールトのスタディ2と並行して行 なわれた。周辺部を回っていたアーケードは、西側のポ ーチの部分だけを残して取り除かれる。この操作によっ
て建物の全体形はH形の輪郭となる。そして、何枚かの 透視図によって、敷地の情景のなかでのたたずまいが検 討されている。平面は、3列のヴォールト（1列のポー チを含む）の西側のウイングと、6列のヴォールトを持 つ東側のウイングが、3列のヴォールトからなる結合部 を介して連結した構成で、建物の主エントランスを持つ 西側のウイングに講堂と企画展示室、東側に常設展示室 が配されている（図5,B）。

後期のものは、ヴォールトのスタディ2が一段落した 段階のもので、建物の南北方向の幅を減じることで全体 形を縮小する操作が中心となる。西側のウイングのヴォ

图3 ヴォールトの䉼面のスケッチ

Louis I. Kahn Collection, University of Pennsylvania and Pennsylvania Historical and Museum Commission 730.39

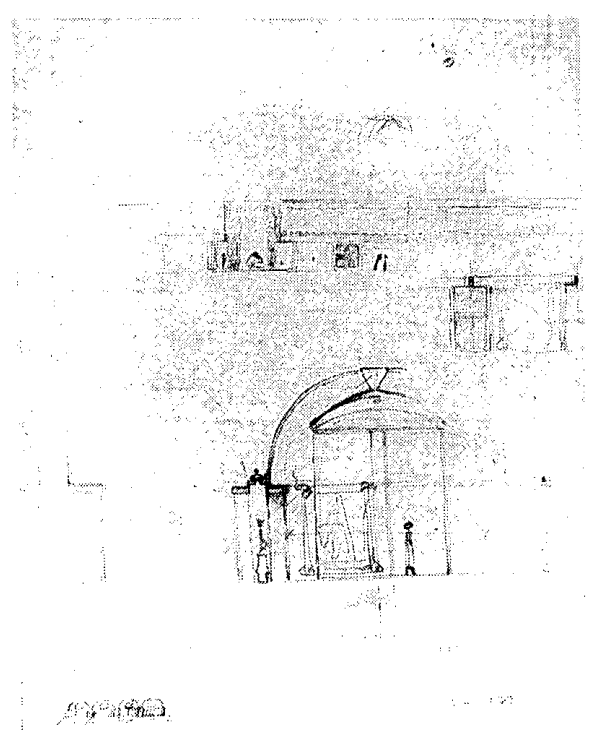

图 4 ウォールトのスタディ 2 における形態変換

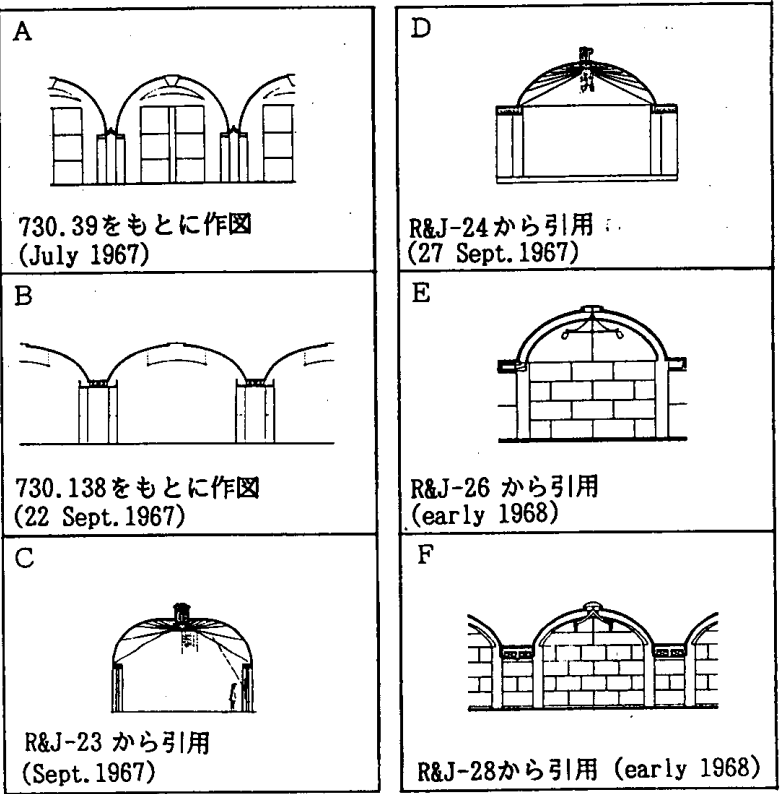


一ルトの数は、4列へと変化しているが、内部の機能の 割り当ては、前期のものと同じである（図5,C）。前・ 後期ともに、地下階には作品搬入や運営に関する多くの 部屋が収容されているが、それらは明確にゾーニングさ れてはいない。

・変遷期の配置・平面のスタデイ 1968年8月 1968年8月には、平面計画において、急激な変化があ らわれる。最初の変化はH形案の変換の流れを受け継い だもので、建物の南北方向の幅を減ずる操作か加えられ、 同時に結合部のヴォールトは軸方向に延長されて、全体 は長方形の輪郭を有するにいたる（図5.D） ${ }^{15)}$

引き続いて行なわれる変換操作は、長方形案の結合部 をエントランス部分とし、ヴォールトの軸方向を南北方 向から東西方向に変更するものである（図5,E）。この 段階でいったんハードラインの図面で、平面と立面の概 略の寸法があたられている。中央部と端部のヴォールト の軸方向の長さは、はじめは異なっていたが、結局同一 の寸法とされ、端部7列、中央部4列のヴォールトから なる基本の平面形が生ずる（図 $5, \mathrm{~F}$ ）。最後に、建物を 敷地に対して回転させて正面を西に向け、ヴォールトの 軸方向は再び南北方向となる（図 $5, G$ )。以上の操作を 通じて、最終のC形平面案の骨格が完成するのである。

・C形平面案の平面のスタディ 1968 年9月から1969年 5 月

このスタディは7列のヴォールトからなる全体形を持 つ前期 (1968年9月から11月) と、6列となる後期 (1969年3月から5月)に分かれるが、全体的なヴォール トの配列は固定され、スタディの主題はヴォールト列数 と寸法の調整による全体形の縮小と、南北両端のウイン グおよび地下部分への各機能の割り当てに移っている。 たとえば、講堂は建物の様々な部分への割り当てが試み られている（図6）。また、地下階では、北側のウイン グに作品搬入関係、南側に運営関係、中央部に設備関係 の部屋が集められており、ゾーニングはH形案よりも格 段に明確になっている。

\section{・その他のスタディ}

C形平面案のスタディと並行して各室の内部空間のス タディが、1968年9月から1970年3月にかけて行なわれ る。対象となるのは図書館、書店、中庭、サービス諸室 などである。特に図書館のスタデイでは、ヴォールトの 空間に中間階を挿入し、上下二層に分けるという大きな 変形がなされているのであるが、ヴォールトの基本形は 完全に維持されている。このことから、このスタディの
根本的なポイントは、ヴォールトの連結という大きな秩 序に個別の機能をどのように織り込ませるのかという点 にあったと考えられる。

また、外構のスタディも、1968年9月から1970年12 月にかけて本格的に行なわれる。敷地全体を構成する要 素は、建物本体、池、駐車場、前庭、既存の並木などで あるが、これらの配列とそれぞれの造作は着工直前の 1969年6月のキンベル夫人宛ての手紙のスケッチ ${ }^{16}$ の時 点で、ほほ決定されている。工事着工後は外構を構成す

图 5 配置・平面のスタア゙イにおける形態変换
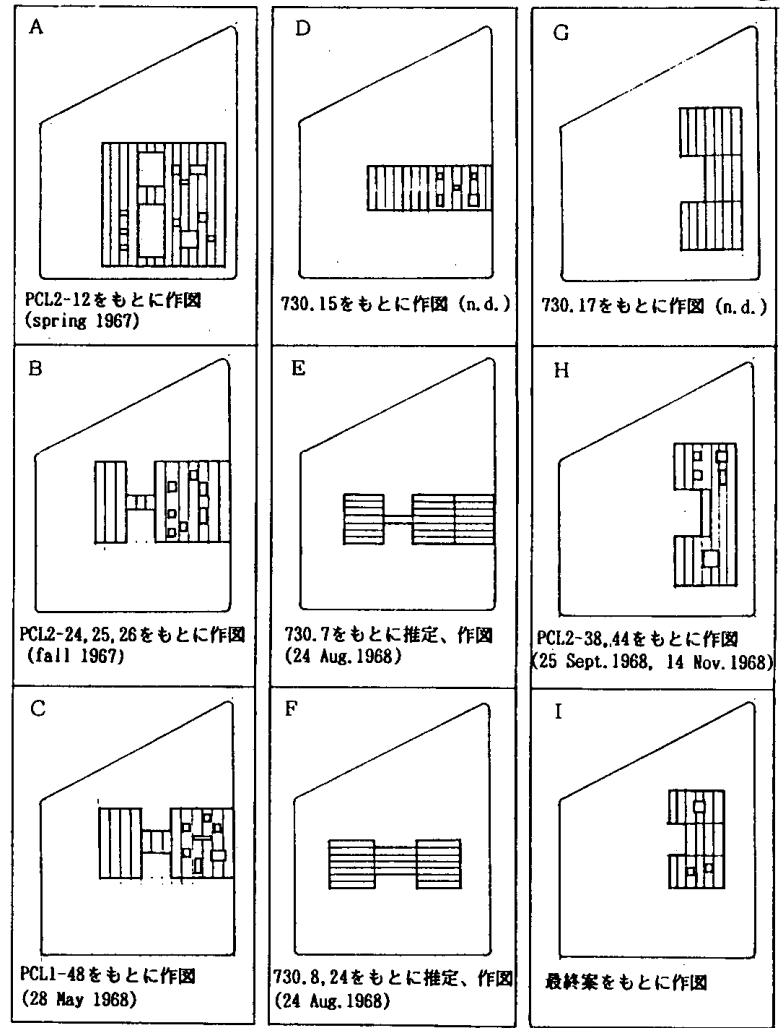

图 6 C 形平面案のスタアイに抽る講堂の位置の変换

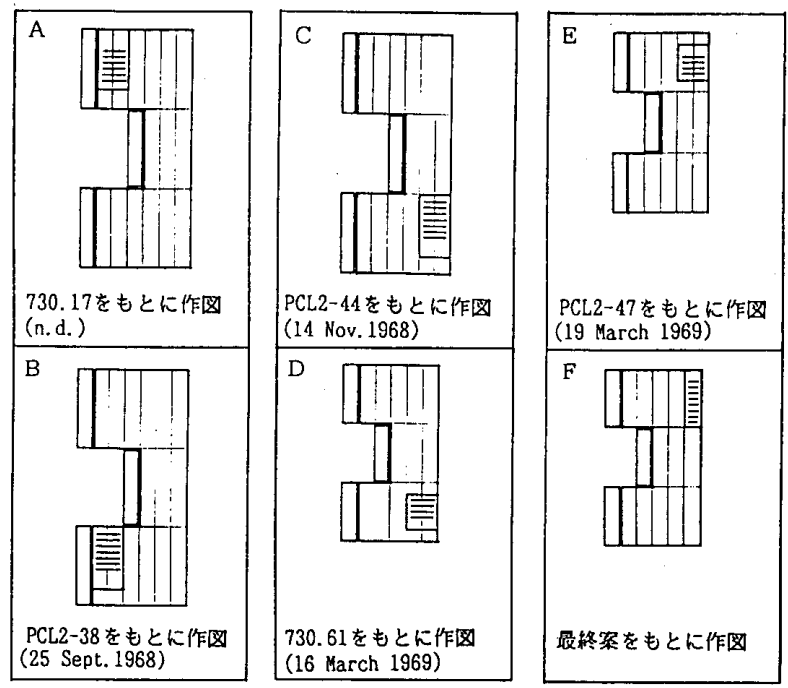


る各要素、およびその細部へと主題が移っていく。

さらに、工事が着工された1969年7月から細部のス夕 ア゙イが本格化する。対象はヴォールト端部の空調吹出口、 石材の目地、採光部の反射板の支持方法、建具などに及 んでいる。これらは最終的に1970年6月1日付の実施設 計図に盛り込まれた

\section{3 スタディの連鎖と内在的条件}

これらの個々のスタディは相互に緊密に関倸して設計 の全体をかたちづくっている。スタデイ相互の関係の分 析は、各スタデイの弁別的特徽息を取り出し、これらの 維持および変化を把握するという方法で行なった。この 結果を表2に示す。

この表から、実質ほほ3年半にわたるキンべルの設計 で、一貫して維持された形態的特徽が、「頂部採光のヴ オールトの水平方向の結合体に対する中庭の挿入」とい う形式としてまとめられることが明瞭に境み取られる。 これをキンベルの設計を導いた基本形式と呼ぶ.199。
この基本形式は、二つの方向の変形を導く内在的条件 を有している。ひとつは、ヴォールト単位の配列を変え ることによる変形であり、もうひとつは、ヴォールト単 位自体の変形である。

正方形、H形、C形と続いた平面の形態変換は、基本 的に前者の変形に基づくものである。ヴォールトは、そ のいくつかが結合されてウイングの単位となり、さらに それらか配列されて建物の全体形をかたちづくるという ように段階的に結合・配列され、機能のゾーニングに対 処している。ヴォールトは軸方向及び軸直交方向に相互 に連結可能であるという特徴を持っことによって、この 変形を支える役割を担っている。

一方、ヴォールト自体の変形は、まずヴォールトのス タデイににおいて、その可能な形態が走查されるという 形で行なわれ、つぎに、ヴォールトのスタデイ2におい て、採光、構造、設備など多面的な検討を通じて、様々 な機能室を収容するために必要な道具立てを得た。この ようにして、ヴォールトは、基本形式を支えるに十分な 形態的特徴を獲得していったのである。

表 2 キンベル美術館の設計におけるスタデイの連鎖

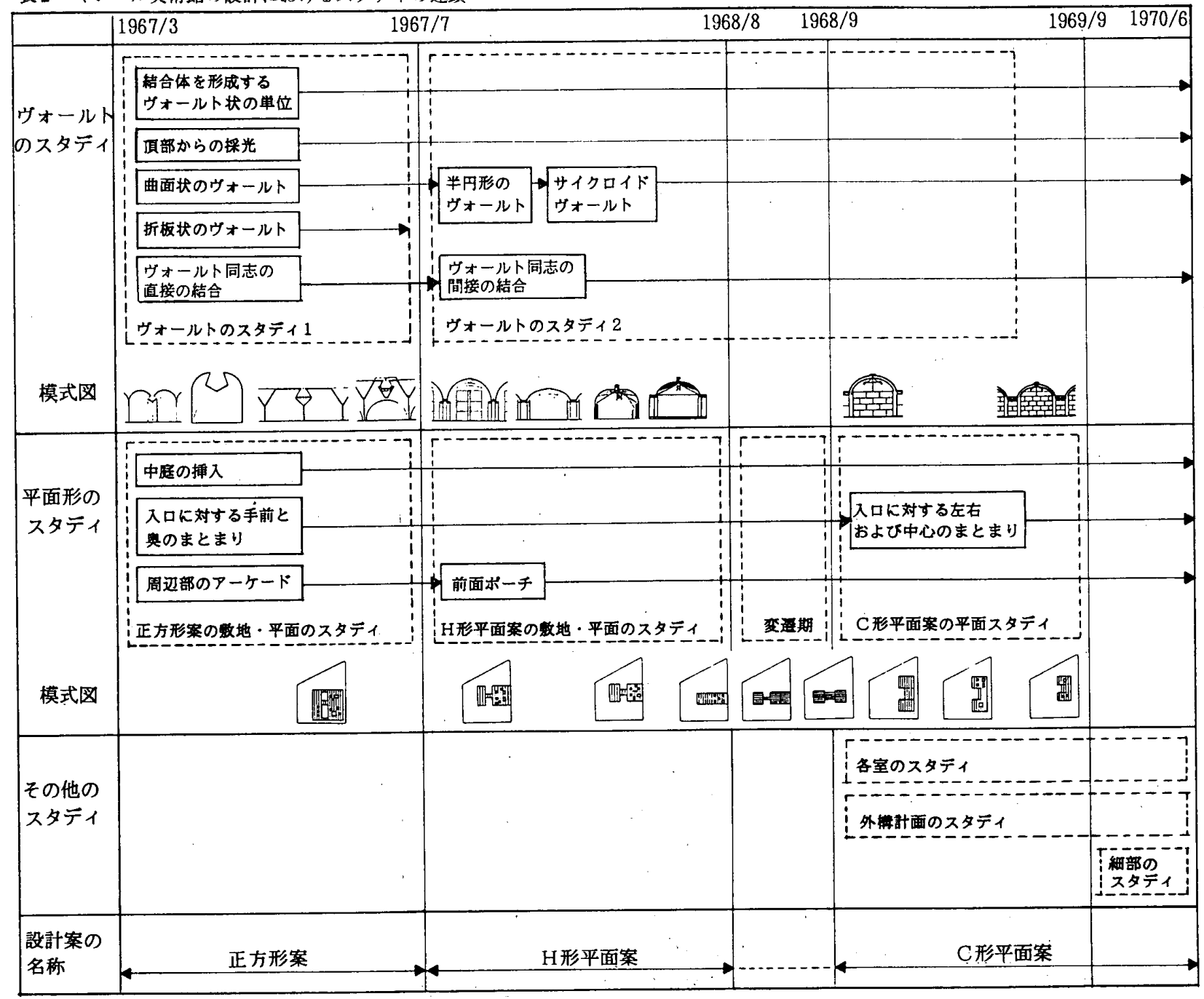


ひきづづく各室のスタティにおいては、すべてのヴォ ールトに共通に適用される変形はもはや行なわれなくな り、ヴォールトの形態を前提として各空間ごとの変形が 行なわれていったのである。

以上のように、基本形式とヴォールトは、設計の論理 の基礎を定めることで、設計過程を導く重要な役割を担 ったのであるが、そればかりではなく、最終の作品形態 にも重要な特質を与えている。来館者は、ヴォールトの 基本形を最も単純直裁に示すポーチに導かれて建物に入 り、その基本形の展開のなかに、エントランス・ホール や展示室、講堂、図書館などの様々な空間が織り达まれ てゆくさまを体験するのである。この体験はまさにこの 作品の辿った設計過程の展開と一致する。「建物が蛂工 して利用されるとき、それは自身が逆った生成の冒険を

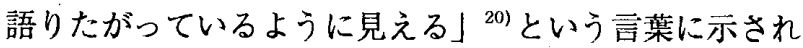
るカーンの問題意識は、彼の設計意図の重要な一部とな って、この作品に結晶していると考えられるのである。

\section{4 内在的条件と設計条件との関係}

基本形式とヴォールトの形態は、キンベルの設計条件 といかなる関わりを持っていたのであろうか。ここでは、 ヴォールトのスタデイ1および2と、変遷期の配置・平 面のスタディを取り上げ、これらとキンベルの建築プロ グラムとの関係について考察する。

ヴォールトのスタディに最も影響を与えた設計条件は、 設計着手にあたって設計者に与えられた建築プログラム である。これはキンベル美術館に招聘された経験豊かな 館長、リチャードF.ブラウンによって起草されたもの である $211 。$

プログラムに示された条件のうち、設計に実際に強く 影響をもったのは、個々の室の面積やコストなどではな く、建築の性格付けや設計にあたって考慮が必要とされ る事項である ${ }^{22)}$ 。プログラムは、これらをきわめて的確 に記述している。このうち特に重要なものを列挙してみ る。

1)：住まいのような暖かで、やさしい優雅な感覚を与 える建物とすべきこと湆

2)：サービス部分、公開部分、連営部分が、各々適切 に、論理的に分節されること分さ

3)：展示には自然光による採光を主要なものとして用 い人工光は補助手段としてのみ用いること ${ }^{25)}$

また、キンベルの敷地に隣接するエイモン・カーター 美術館 ${ }^{26)}$ からのダウンタウンの眺めを妨げることのな いように、キンベルの評議会は次の条件を付け加えた。 $4)$ : 建物の高さを40feet（約 $12.2 \mathrm{~m} ）$ 以上としない ${ }^{27)}$
これらの条件に対し、形態分析によって得られた、 「頂部採光のヴォールトの水平方向の結合体に対する中 庭の挿入」という基本形式が適合していることが読み取 られる。ゆえにこの形式を維持しつつ変形を行なうかぎ りにおいて、生成される全ての形態は、4)の条件を常 に満足する。また、1),3)の条件はヴォールト単位自体 の変形に問題が置き換えられ、さらに、2)の条件はヴ オールトの配列の変形に問題が置きかえられる。このよ うにして、平面のスタディにおける形態変換が従うべき 基本的秩序が与えられたのである。

ところが、プログラムには、スカイライトなどによる 頂部からの採光が、好ましい解答でないことがはっきり

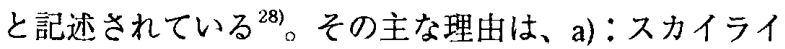
トからは外部を直接見ることができず、雲围気の自然な 変化が内部から感じられないこと、b)：スカイライトが 一般に大きな無駄な空間を必要とすること、の2点であ る。ここでも基本形式、およびヴォールトの形態の発展 の方向との適合性が観察される。すなわち、a）の理由 の解除には、中庭の扱入と、広い前庭に面したポーチが 大きな役割を果たし、また、b) の理由の解除には、採 光部に反射板を用いることによって、頂点の高さの低い ヴォールトの可能性が開かれたことが、大きな役割を果 したのである ${ }^{29)}$

基本形式の、設計を秩序づける能力が最もよく発揮さ れたのは、変遷期の配置・平面のスタディである。この スタディは、H形案の西側のウイングのエントランスの すぐわきに企画展示室が位置しており、企画のない場合、 来館者にさみしい印象を与えてしまうのではないかとい うブラウンの指摘に影響されて始まったものである゙0。

この指摘は平面計画にきわめて大きな影響を与えるも のであり、仮に一般的な設計のように平面計画を主軸と して設計を行なっていたとするならば、プログラムに示 されている最も重要な課題の解决から設計をやり直すこ とを余儀なくされ、建築物の形態は根本的に変化したで あろう。しかし、実際には、ヴォールトの形態が維持さ れつつ、C形の平面が生み出される形で、この問題は短 時間のうちに解決されだ1。これは、新たに提出された 設計条件を、変遷期のスタデイの項で明らかにしたよう なヴォールトの配列の変形へと結び付ける道筋を基本形 式が準備していたからであり、また、その変形がヴォー ルト自体の変更を伴わずに行ないうる内在的条件が成立 していたからである。

以上のように、基本形式とヴォールトの形態は、設計 条件と内在的条件を適切に対応させ、安定に設計を導く 能力を持ったのである ${ }^{32)}$ 。 


\section{3. カーンの作品群に見られる結合の手法}

それではなぜカーンはこの基本形式とヴォールトを設 計条件に適切なものとしてあてはめることができたので あろうか。ルードは、カーンに影響を与えたと考え得る 様々なヴォールトを建築史から引き出して検討を加えて いる ${ }^{33)}$ 。これらの実例は、確かにカーンに一定の影響を 与えたに違いない。カーン自身も、歴史的遺産に目を向 け、設計に生かすことを常に説いていたのである ${ }^{34)}$ 。し かしこのきっかけを自らの手法に変え、設計のなかで形 態を生き生きと生成させるには、カーン自身の側にもこ れを成長させる土壤がなければならないはずである。

この土潩は、同一形龍の単位を相互に結合して建築物 の全体形を作り上げる形式として、カーンのキンベル以 前の作品群の中に明暸にあらわれている。単位となる形 態要素は、パラソル・ハウス（1944）や、オリヴェッ ティ・アンダーウッド工場（1966-70）（図7,A）など に見られるパラソル形のユニットや、アドラー邸

(1954-55）や、ユダヤ・コミュニティ・センター （1954-59）（図7,B）に見られる正方形平面の空間単 位のユニット（以下セル・ユニットと呼ふ）であって、 ヴォールトはほとんど見られない ${ }^{35)}$ 。しかし、これらの エニットも初期のものを除いて、採光部や設備や構造の 処理のための従属的空間を持つなど、キンベルのヴォー ルトと共通の特徵を有している。

この点に注意するならば、カーンがヴォールトに着目 した内なる力とは、自らが有していたこれらのユニット ・ ボキャブラリーであったと言うことができるであろう。 また、歴史的遺産から取り出されたヴォールトが、キン ベルの設計を通じて、設計者のボキャブラリーの中の一. 員として位置づけられるにいたったのだととも解秎でき る。そして、キンベルの設計ののち、ヴォールト・ボキ ヤブラリーによる結合の形式は、ウォルフソン・センタ - (1968-1974) や、イエール大学英国美術研究センタ 一の中間案（1969-74）（図7,C）などの設計おおいて、 複合されつつ文字どおり開花してゅくのである。

キンベルをはじめこれらの作品に見られるユニット． ボキャブラリーの結合の形式は、「平面は、部屋の社会 である」という彼の有名な定式を、最も直裁に表現する ものでもある ${ }^{36)}$ 。そして、この形式は、秩序だった空間 の展開の表現をカーンの作品に与えると同時に、彼の

「きびしく方法論的な」 ${ }^{37)}$ 設計態度を示す証拠ともな っているのである。

\section{4. 結論}

以上の分析の結果を、基本形式とヴォールトが設計に おいて果した役割という点からまとめてみよう。
カーンはキンベルの設計課題に対して、「頂部採光の ヴォールトの水平方向の結合体に対する中庭の挿入」と いう基本形式を当てはめた。この基本形式は、ヴォール トの配列の変形と、ヴォールト自体の変形という二つの 方向で、形態を生成させる内在的条件を有していた。ま た、基本形式は重要な設計条件を形態に結び付ける作用 を持ち、設計条件のうち、平面計画に関するものは前者 に、個々の部屋の機能や内部空間の特質に関するものは 後者に関係づけられた。そして、この基本形式は設計過 程全体にわたって維持された。

相互に連結可能なヴォールトの形態は、様々な機能を 内包するのに必要な道具立てを設計過程において獲得し ていき、基本形式を支える重要な役割を担った。ヴォー ルトのスタデイは初期に発散的に、後期では収束的に行 なわれ、各室の設計に大きな影響を与えた。この影響は、 作品形態に秩序だった空間の展開という特質を与えるも のでもあった。

さらに、ヴォールトは、キンベルの設計を通じて、パ ラソルユニットやセルユニットと並ふ、カーンの設計ボ キャブラリーの一貝となり、キンベルの設計を越えた生 命力をもって、キンベル以後の作品の設計のなかでめざ ましい展開を見せたのである。

図 7 カーンの 3 種のユニット・ボキャブラリー
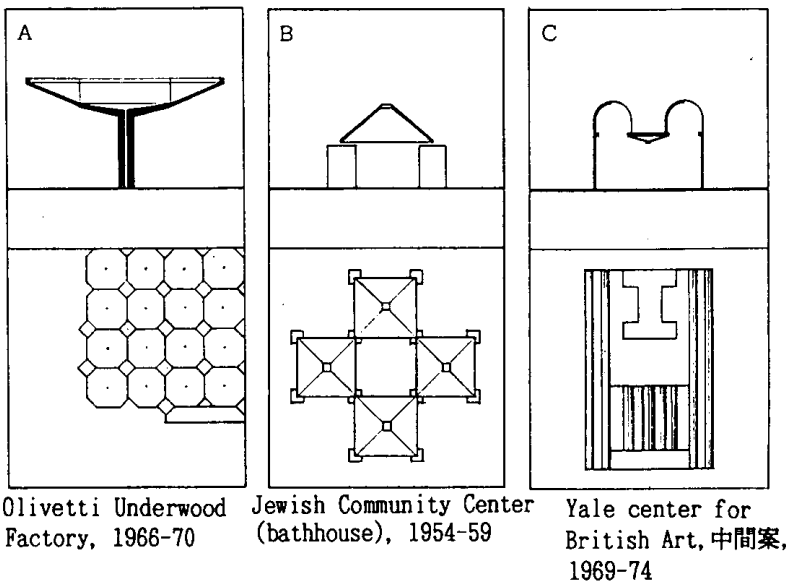


\section{注および参考文献}

1) Kimbell Art Museum. 住所は 3333 Camp Bowie Boulevard, Fort Worth, Texas., U.S.A.

2) The Louis I. Kahn Collection, The Architectural Archives, Graduate School of Fine Arts, University of Pennsylvania. 102 Meyerson Hall, Philadelphia, PA 19104-6311 U.S.A.

3) Kahn, Louis I. : The Louis I. Kahn Archive, PERSONAL DRAWINGS, The Completedly Illustrated Catalogue of the Drawings in The Louis I. Kahn Collection, University of Pennsylvania and Pennsylvania Historical and Museum Commission, Volume 1-7, Alexander Tzonis, General Editor, Garland Publishing Inc., New York and London, 1987. 本稿中で はGARの記㕺で表す。

4) Ronner, Heinz and Jhaveri, Sharad : Louis I. Kahn Complete Work 1935.74, second revised and enlarged ed., Institute for History and Theory of Architecture, The Swiss Federal Institute of Technology (ETH), Birkhaeuser, Basel and Boston, 1987. 本稿中で はR\&Jの記照で表す。

5) Loud, Patricia Cummings : History of the Kimbell Art Museum , Kimbell Art Museum: In Pursuit of Quality - The Kimbell Art Museum, Fort Worth, Abrams, 1987.に所収。本稿中ではPCL1の 記号で表す。

6) Loud, Patricia Cummings : The Art Museums of Louis I. Kahn, Duke Univesity Press, Duke University Museums of Art, 1989. 本 稿中ではPCL2の記号で表す。

7) Loud, Patricia Cummings : Kimbell Art Museum, Brownlee, David B.and De Long, David G.: Louis I. Kahn - In the Realm of Architecture, The Museum of Modern Art, Los Angeles, Rizzoli, 1991. に所収。本稿中ではPCL3の記号で表す。

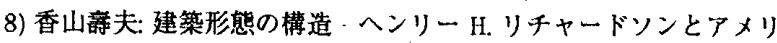
力近代建築, 東京大学出版会, 1988, pp.1.

9) 設計条件と形態の適合性については、Alexander, Christopher, 稲 葉武司訳: 形の合成に関するノート（原題: Notes on the Synthesis of Form）,鹿島出版会, 1978 （原著1964）。の第 2 章を参照。

10）配置計画と平面計画を基本的に同一のスタデイと报っているの は、キンベルの場合敷地上の建物の配置と建物の全体形が常に对 応しており、独立した挙動が見られないからである。

11) Meyers, Marshall: Master of Light - Louis I. Kahn, AIA Journal, Sept. 1979, pp.60-62.

12) 反射板等の細部の検討については、Meyers の前揭菁を参照。

13)この段階でのヴォールトは、建筑構造としてはシェル構造であ る。この経糢に関しては、Komendant, August E., 小川英明訳: ル イス・カーンとの十八年、明現社, 1986 (原著1975). 参照。

14）GARの730.4は表焼きで揭載されている。

15) R\&JおよびPCL1は、長方形案と呼ばれるこの案を、正方形案と H形案の中間案としているが、時期の同定が可能なGAR 730.46 (20 Aug.1968)と、配置図 730.15 の特徵がきわめてよく一致する ことから、長方形案はH形案に引き続くものであると証明される。 いずれにせよ、この案はこれ以上梁く追求されることはなかった。 PCL2, pp.124参照。

16) PCL2, 図版3.54参照。

17）実施設計図は、共同設計を行っていた地元のGeren杜によって主 に作成された。

18) 香山, 前揭曺, pp.14参照。

19）カーン自身もファースト・ユニタリアン教会の設計の展開を、 設計過程全体にわたって維持された「フォーム」と、それに基づ いて展開された「デザイン」の二つの段階で説明している。Louis I. Kahn: Form and Design, Scully, Vincent：Louis I. Kahn, に所取、 pp.116 117. 参照。
20) Louis I. Kahn : Architecture: Silence and Light, 1970. Alessandra Latour ed., Louis I. Kahn - Wrightings, Lectures and Interviews, Rizzori, 1991. pp.248を参照。

21) Richard F. Brown から設計者に与えられた建築ブログラムは、 美術館の運営の方針を示すPolicy Statementと、建物に必要とされ る事項をまとめたPre-Architectural Programの二部に分けられて いる。これらの両方には1966年6月1日の日付が付けられている。 Kimbell Art Museum: In Pursuit of Quality, The Kimbell Art Museum, Fort Worth, 1987. Appendix 1および2に所収。

22）カーンの設計ブログラムに対する態度を示す言背として、たと えば Louis I. Kahn: Robert Wermischner との会話, 17 April 1971; Wurman, Richard S.: What will he has always been, Acesess Press, 1986. pp.120を参照。

23) Brown: Pre-Architectural Program, I - C

24) Brown: 前揭㝜, IV - C

25) Brown: 前揭書, X - A

26) Pbilip Johnson の作品。

27) PCL3. pp.396参照。

28) Brown: 前揭書, $X \cdot A \cdot 2$

29）Brown は内部空間のスケール・オーバーの危険性を、設計の最 中に繰り返し指摘していた。 Meyers：前揭書参照。

30) PCL2, pp.124; PCL3, pp.398参照。

31) スケッチから見るかきり、重要な変化は1968年8月24, 25日の 2 日間に起こっている。その約 1 カ月後の9月26日にはC形平面案の オフィス・ドローイングがBrownあてに発送された。PCL2, pp.124参照。

32）館長Brownと、設計担当者のMeyersは、このヴォールトの能力 を正確に把握していた。河崎一美: Marshall Meyers に対するイン タどュー，建築と都市，1983年11月 臨時増刊号, pp.197 および pp.225 を参照。

33) PCL1,pp.34以降を参照。

34) カーン自身も、キンベルの竣工式のスピーチでローマのヴォー ルトについて言及している。Wurman, Richard S.: 前揭青, pp.177参照。

35) Yale Art Gallery (1951-53)の中間案には、展示室の天井がウォ ールトの練り返しでつくられたものがある。また、Reserch Institute for Advanced Science (1956 58) の中間案には、クロス. ウォールトの単位が見られるが、いずれも萌芽的なものである。

36) カーンは、ヴォールトの単位を部屋（Room）と呼んでいる。 Kahn, Louis I. : William Jordy との会話, Wurman, Richard S. : 前 揭菖, pp.238. 参照。

37) Scully, Vincent: Rigourously Methodological, 国際建築1967年1月 号, pp.10-12. 参照。

(1993 年 7 月 8 日原稿受理, 1994 年 5 月 30 日採用決定) 